\title{
POLA REKRUTMEN POLITIK BERDASARKAN IDEOLOGI PARTAI POLITIK DALAM SISTEM KETATANEGARAAN INDONESIA
}

\author{
Else Suhaimi*
}

\begin{abstract}
Political recruitment is a process of selecting and selecting a person or several members of the community to occupy and exercise certain political roles as cadres of political parties, legislators, as president and vice president and as regional head. In the Indonesian state system, this political recruitment is left to political parties. The rise of political parties as a result of freedom of association and assembly on the one hand is a reflection of democracy but on the other hand the large number of political parties will give rise to increasingly tight competition between political parties. The increasing competition makes political actors easily trapped in political pragmatism. Political pragmatism as a short-term orientation of political actors to win political competition is power. The Power as the ultimate goal of the political competition. Political pragmatism has had a significant impact on the formation of pragmatic recruitment patterns. The pattern of pragmatic recruitment has spawned many problems, especially issues related to the quality of recruitment results. One of them is that many of the political elites are facing legal problems such as corruption and so on. Under these conditions emerged initiatives to present a systematic and structured pattern of political recruitment. One of the indications is that political recruitment is based on the ideology of political parties. The ideology of a political party is broadly divided into recruitment based on Islamic ideology (religion) and other ideologies such as nationalism. The closer the party ideology to the party recruitment pattern will result in quality recruitment and visionary cadres. On the contrary, the further distance the party ideology with the party recruitment pattern will result in a pragmatic recruitment. The results of recruitment have a close relationship with the quality of products produced, especially product legislation.
\end{abstract}

Kata Kunci: pola rekrutmen, partai politik, sistem ketatanegaraan

Salah satu fungsi partai politik yang mendapat sorotan publik adalah fungsi rekrutmen. Dalam peraturan perundang-undangan Pasal 29 UU No. 2 Tahun 2011 tentang Partai Politik, partai politik berfungsi untuk menyeleksi dan memilih atau mengangkat seseorang atau beberapa orang anggotanya atau anggota masyarakat lainnya untuk menduduki dan melaksanakan peranan politik tertentu dalam pemerintahan atau di luar pemerintahan yaitu sebagai anggota partai politik, anggota legislatif dan kepala daerah. Fungsi ini akan semakin besar kalau partai yang bersangkutan merupakan partai yang mempunyai wakil-wakil yang mayoritas di parlemen baik di tingkat pusat maupun di tingkat daerah (Setiadi dan Usman Kolip, 2013: 283).

Pada tahun 1946 merupakan awal pembentukan partai politik dan sekaligus rencana pembentukan lembaga perwakilan melalui pemilihan

*Program Doktor Ilmu Hukum Fakultas Hukum, UNSRI, koresponden penulis via email:elsehadi@gmail.com 
umum. Akan tetapi pemilihan umum tersebut baru terlaksana pada tahun 1955. Pemilu pertama tersebut merupakan rekruitmen politik pertama bagi calon anggota legislatif atau badan perwakilan. Pola rekruitmen tersebut sangat tergantung pada sistem politik yang ada pada saat itu. Sistem multipartai merupakan salah satu kondisi yang tidak terelakan. Partai politik juga menghadapi situasi yang belum stabil karena masih berhadapan dengan agresi Belanda dan perbedaan ideologi partai serta sistem pemerintahan yang belum berjalan stabil. Maka dalam kaitannya dengan peran partai politik tersebut, rezim Soekarno melihat partai politik, sebagai sumber kekacauan dari sistem politik yang mereka bangun. Karena itu, keinginan untuk menyederhanakan partai politik kerap muncul dalam rangka menciptakan kestabilan politik (Budiardjo, 2008: 448).

Perbedaan ideologi partai politik di awal pertumbuhannya memberikan perbedaan pandangan berkaitan dengan penentuan dasar negara Republik Indonesia. Perbedaan pandangan dalam perdebatan itu mengkrucut pada dua ideologi yang diperjuangkan yaitu Islam dan nasionalis dan sosialis. Ketiga ideologi tersebut diusung oleh partai politik yang mendapat dukungan besar di masyarakat yaitu Partai Masyumi, PNI, NU dan PKI (Budiardjo, 2008: 442).

Dari keempat partai politik tersebut partai Masyumi terpaksa membubarkan diri karena sistem politik yang tidak mendukung salah satunya adalah perubahan sistem politik dari demokrasi liberal ke demokrasi terpimpin. Di mana dalam demokrasi terpimpin Presiden memegang kendali terhadap partai politik. Karena partai Masyumi tidak setuju dengan demokrasi terpimpin maka, sebelum dibubarkan oleh Presiden Soekarno, Partai Masyumi terlebih dahulu membubarkan diri. Pendukungpendukung Masyumi dari berbagai ormas, dan kelompok masyarakat satu persatu melepaskan diri (Lili Romli, 43).

Di era orde baru sistem politik sistem politik yang dibangun berasaskan pada demokrasi Pancasila. Atas nama demokrasi Pancasila, keberadaan partai politik belum mendapatkan tempat yang layak. Partai politik yang merupakan manifestasi ideologi masyarakat tidak terjadi. Pancasila sebagai ideologi bagi masyarakat dan partai politik hanya dapat teraplikasi secara formalitas dan procedural. Secara riil Pancasila belum dipahami secara ideologis. Penerapan Pancasila dalam kehidupan politik justru membelenggu partai politik. Ideologi partai politik disederhanakan melalui fusi yang melahirkan dua partai politik yaitu PPP yang mewakili Islam dan PDI yang mewakili nasionalis, serta Golkar yang tidak di antara keduanya.

Secara sosial politik Golkar bertahan sebagai partai tunggal yang mendapatkan dukungan terbesar di masyarakat bertahan selama 32 tahun. Selama kurun waktu tersebut, Golkar telah berhasil membentuk suatu hegemoni politik di masyarakat yaitu setiap Pemilu dapat dipastikan Golkar sebagai pemenang.

Memasuki era reformasi, hegemoni politik Golkar dihancurkan dengan dibukanya kran pembentukan partai-partai politik baru. Golkar pun harus berubah menjadi partai politik agar bisa mengikuti Pemilu. Partaipartai politik yang baru dibentuk tetap mengarah pada dua ideologi besar yaitu Islam dan Nasionalis dengan berbagai variasi. Ibarat makanan maka Islam dan Nasionalis merupakan makanan pokok. Pada saat dihidangkan 
makanan pokok tersebut bisa ditambahi dengan berbagai varian rasa dan model penyajian. Akan tetapi kenyataan yang dihadapi sekarang terlihat varian rasa dan model penyajiaanya lebih mendapat perhatian, akibatnya kita lupa dengan keaslian dari makanan pokok yang seharusnya kita makan. Ini merupakan sebuah ironi.

Secara konstitusional, keberadaan ideologi dan partai politik merupakan sebuah keniscayaan karena partai politik merupakan perwujudan kekuatan yang nyata dalam masyarakat. Kata lain dari kekuatan yang nyata dalam masyarakat itu adalah ideologi. Sejarah masyarakat telah membentuk dua ideologi yaitu Islam dan nasionalis. Akan tetapi kedua ideologi tersebut berusaha dibenturkan sehingga kelihatan seram dan menakutkan. Sehingga muncullah partai politik dengan ideologi yang samar-samar. Hal ini secara sosial politik memberikan dampak kepada masyarakat dan juga bagi partai politik. Dampak tersebut terlihat pada aktivitas politik partai politik dalam melaksanakan fungsinya.

Menurut Paraniari Siahaan, untuk mengetahui kinerja partai politik di Indonesia dapat dilihat dari efektifitas partai politik menurut fungsi ideal partai politik yaitu; Pertama, disfungsi rekruitmen, proses rekruitmen didasarkan atas karir politik di partai politik, tawar menawar kepentingan, dan juga the money of candidate (mahar) bukan atas dasar the capability and credibility of candidate. Kedua, disfungsi komunikasi politik, proses ini berjalan searah dimana komunikasi bersifat top-down dan bukan bottom up sehingga artikulasi kepentingan rakyat tidak berjalan yang berakibat tidak terakomodirnya kepentingan rakyat dalam proses pembuatan kebijakan publik. Ketiga, disfungsi sosialisasi politik. Fungsi ini hanya dilakukan ketika waktu pemilu sudah dekat (kampanye), artinya ketika proses pemilu berakhir partai politik melupakan konstituennya dan sibuk dengan target pencapaian kepentingan politik praktis. Dan kelima, disfungsi manajemen konflik, bukannya me-manage konflik melainkan justru menjadi biang konflik sehingga instabilitas politik terjadi dimana penuh dengan pertarungan kepentingan anta relit, konflik antarparpol, konflik antar kelompok kepentingan dan konflik berdimensi horizontal antar masyarakat (Pataniari Siahaan, 2016)

Pada pelaksanaan fungsi rekruitmen ini, terdapat fenomena "naturalisasi" kader partai politik dari satu partai ke partai lain. Ini menandakan bahwa lemahnya sistem rekrutmen dan pola kaderisasi tersebut masih cukup memprihatinkan dan lunturnya ideologi partai politik. Idealnya, jika rekrutmen dan pola kaderisasi kader dilakukan dengan baik oleh setiap partai politik maka kita tidak akan menemukan lagi fenomena "berkhianat" dari partai politik asalnya. Karena partai politik yang berfungsi sebagai kawah candradimuka yang digunakan untuk menempa dan menggembleng para kadernya untuk kemudian diproyeksikan sebagai pengisi jabatan-jabatan politik di pemerintahan telah mempunyai keterikatan emosional dan keterikatan ideologi antar para kadernya tersebut (Labolo dan Teguh Ilham, 2014: 197).

Pada rekruitmen terhadap kepala daerah, persoalan yang berhubungan dengan dinasti politik, Petahana, kasus korupsi, suap menyuap, narkoba, tindak kekerasan, pelanggaran etika dan permasalahan yang menyangkut fundraising (pendanaan). 
Untuk melakukan pencalonan kepala daerah maka partai politik atau gabungan partai politik pengusung calon kepala daerah disyaratkan telah memenuhi persyaratan perolehan paling sedikit 20\% dari jumlah kursi DPRD atau $25 \%$ dari akumulasi perolehan suara sah dalam pemilu anggotan DPRD di daerah yang bersangkutan. Pencalonan dengan syarat tersebut telah mengkondisikan partai politik untuk berkoalisi antar partai. Koalisi ini telah membuka kran untuk terjadinya kesepakatan-kesepakatan politik yang berorientasi pada kepentingan kekuasaan.

Data perolehan suara 12 partai politik memperlihatkan bahwa Pemilu tahun 2014 merupakan era mundurnya loyalitas pemilih terhadap partai politik hingga $20 \%$. Ini menunjukkan persoalan rendahnya identifikasi diri dengan partai politik yang dipilih dan juga memberikan indikasi identitas dari partai politik di tengah masyarakat tidak tampak, semua partai politik dianggap sama. Identitas partai politik tersebut dapat dibedakan antara partai yang satu sama lain melalui ideologi atau paradigm dari partai politik tersebut (Firmansyah, 2011: 198).

Secara formal, ideology partai politik dinyatakan dalam dokumen AD/ART partai politik masing-masing. Akan tetapi ideology tersebut pada kenyataannya tidak tercermin dalam prilaku partai politik. Sulitnya untuk menentukan ideology sebuah partai politik dikarenakan partai yang tidak menampilkan secara murni ideology partai politik mereka (Labolo dan Teguh Ilham, 2014: 191)

Fenomena lunturnya ideology partai juga terjadi pada koalisi yang dibentuk di tingkat daerah. Terjadi "perselingkuhan" partai pada tingkat daerah. jika di pusat Partai Demokrat (PD) merupakan oposisi dari Partai Demokrasi Indonesia Perjuangan (PDIP), maka di tingkat daerah mereka kerap membentuk koalisi. Hal ini memperlihatkan kepada kita bahwa ideology bukanlah segala-galanya bagi partai. Terserah apapun ideologinya, asalkan koalisi yang dibangun mendatangkan keuntungan, setidaknya keuntungan jangka pendek bagi partai, maka partai tidak segan-segan untuk bergabung dengan partai lain. Walaupun dalam perjalanan koalisi sering terjadi perseberangan pendapat sehingga pemerintahan yang mereka bangun menjadi tidak efektif karena selalu diwarnai oleh perseteruan. (Labolo dan Teguh Ilham, 2014: 196).

Paradigma baru pemerintahan menuntut kegiatan nyata kepala daerah yang diarahkan pada kegiatan-kegiatan yang kreatif, inovatif, perintisan, orientasi masyarakat, orientasi pelayanan dan pemberdayaan. Konsep yang sedemikian itu menuntut kualitas kepala daerah sebagai pemimpin organisasi pemerintah daerah makin tinggi pula, di mana seseorang pemimpin tidak cukup hanya mengandalkan intuisi semata, tetapi harus didukung oleh kemampuan intelektual dan keahlian yang memadai, ketajaman visi, serta kemampuan etika dan moral yang beradab. Memahami beratnya tugas dan tanggung jawab kepala daerah, sehingga tidak heran bila pejabat tersebut dituntut oleh persyaratan kualitas yang cukup berat. ( J. Kaloh, 2010: hlm.3).

Perkembangan ketatanegaraan Indonesia dari masa ke masa terdapat permasalahan yang bersifat paradoks, dimana penyelesaian permasalahan ketatanegaraan seolah-olah selesai akan tetapi sesungguhnya menimbulkan masalah baru atau dengan kata lain bila ditinjau secara sepintas lalu, bahwa 
pemecahan suatu masalah malah menimbulkan masalah yang baru pula (Suriasumantri, 2013: 209).

Fungsi rekrutmen oleh partai politik tersebut melahirkan persoalan kaderisasi partai politik yang belum mempunyai pola atau susunan yang sistematis dan terstruktur. Masing-masing partai politik memiliki pola sendiri-sendiri yang tidak terhubung satu sama lain dalam suatu sistem ketatanegaraan dan sistem hukum. Sehingga terlihat pola rekrutmen oleh partai politik berada di area yang bebas. Padahal pola rekrutmen tersebut pada akhirnya berdampak pada aspek ketatanegaraan yang lebih luas.

Dampak atau akibat dari pola rekrutmen politik yang tidak tersistematis Indonesia terancam kekurangan negarawan yang merupakan salah satu akibat dari tidak berjalannya fungsi rekrutmen oleh partai politik karena sikap pragmatism partai politik, kaderisasi partai politik hanya sebatas teori. Sikap pragmatism partai politik tersebut hanya bertujuan untuk meraup suara sebanyak-banyaknya saat Pemilu. Untuk itu dalam rangka meraup suara tersebut, partai politik lebih memilih calon yang bermodal kuat dan telah mendapat dukungan atau sudah dikenal oleh masyarakat dan sebagainya (Koran Kompas, 23 Januari 2017: 2).

Untuk itu menurut Saldi Isra, diperlukan untuk meredesain ulang partai politik mulai dari aturan hingga konsep pendanaan dan rekrutmen. Redesain parpol tersebut diharapkan mampu menciptakan partai politik yang sehat dan betul-betul memperjuangkan kepentingan rakyat. Rekrutmen terhadap anggota dewan harus menghasilkan tokoh yang amanah, bertanggung jawab, memiliki visi kebangsaan dan berkomitmen bahwa bangsa ini didasarkan pada kedaulatan rakyat (Kompas, 27 Februari 2017: 16).

Salah satu dampak yang tampak dewasa ini sebagai akibat dari rekrutmen politik terlihat banyaknya kader partai politik, calon anggota dewan, calon presiden maupun calon kepala daerah. yang tidak berintegritas dan komitmen terhadap kepentingan rakyat. Hal ini terlihat banyaknya kasus-kasus yang menimpa para penyelenggara negara khususnya yang menimpa pada anggota dewan. Seperti kasus korupsi maupun suap. diberitakan bahwa DPR jadi lembaga terkorup terkait pengadaan KTP Elektronik. Pemberitaan tersebut berdasarkan hasil survey yang dilakukan Global Corruption Barometer (GCB). Hasil survey tersebut, untuk Indonesia, DPR dianggap paling korup. Hasil survey tersebut terkonfirmasi antara lain dengan adanya sejumlah anggota DPR yang terlibat dalam kasus korupsi, salah satunya adalah kasus pengadaan KTP elektronik (KTP-el) tahun anggaran 2011-2012 yang sedianya akan disidangkan pada 9 Maret mendatang (Kompas, 8 Maret 2017: 2).

Begitupun dalam penyelenggaraan Pilkada, di mana dalam mengusung calon kepala daerah harus memenuhi persyaratan $20 \%$ dari perolehan kursi di DPRD atau $25 \%$ dari suara partai politik. Artinya untuk memenuhi persyaratan tersebut harus dilakukan koalisi partai politik. Menurut peneliti Centre for Strategic (CSIS), Arya Fernandes, dalam Kompas, 2 Maret 2017, menuturkan, "dari sisi ideal, seharusnya koalisi partai politik ditentukan berdasarkan ideology atau kesamaan program. Namun sulitnya mewujudkan kondisi ideal itu juga tidak terlepas dari persoalan desain institusional, sehingga akhirnya koalisi tersebut ditentukan untuk survival dan kekuasaan. 
Prilaku dari para anggota dewan dan motivasi dari koalisi tersebut berdampak pada produk peraturan perundang-undangan yang dikeluarkan. Banyaknya yudisial review ke Mahkamah Konstitusi memberikan indikasi ada persoalan asasi yang terdapat dalam peraturan perundang-undangan tersebut. Begitupun dengan koalisi pengusungan calon presiden maupun calon kepala daerah memberikan peluang untuk diadakannya kesepakatankesepatan antar partai politik dengan pemerintah yang kelak akan dibentuk.

Untuk itu perkembangan demokrasi dan politik telah menuntut terjadinya reformasi di setiap sisi kehidupan. Dalam demokrasi akan terbentuk suatu konstelasi atau gambaran keadaan kekuatan politik yang terdiri dari kelompok partai politik, kelompok sosial masyarakat, dan lembaga negara. Dihubungkan dengan konsep negara hukum maka sistem politik tersebut akan mempengaruhi terbentuknya peraturan perundangundangan. Peraturan perundang-undangan yang dilahirkan tersebut akan menjadi faktor penentu dalam menghadirkan kehidupan sosial dan politik dalam masyarakat Indonesia sehingga pengaruh keduanya merupakan pengaruh yang timbal balik.

Terkait dengan fungsi partai politik terdapat hubungan yang erat antara pola rekrutmen dengan pencapaian kinerja pada suatu institusi. Rekrutmen yang baik akan memberikan hasil yang baik dalam penyelenggaraan suatu institusi tak terkecuali institusi negara. Dalam aturan perundang-undangan penyelenggaraan rekrutmen politik diberikan kepada partai politik.

Pembangunan sistem kepartaian tidak terlepas dari banyaknya kasuskasus hukum yang menimpa elit politik. Pembangunan partai politik dihadapkan dengan pertumbuhan jumlah partai politik yang bertambah, sehingga sistem multipartai tidak dapat dihindari. Untuk itu kajian ini fokus pada bagaimana pola rekrutmen politik berdasarkan ideologi Islam dan nasionalis dalam sistem politik multipartai.

\section{Partai Politik dan Ideologi}

Asal usul dari partai politik sulit dipisahkan dari evolusi masyarakat dan negara modern. Peran satu partai sering berubah kalau kondisi politik di suatu negara berubah, terutama pada masyarakat yang menjadi modern, di mana perkembangan politik bisa menyebabkan perubahan yang luas dan kompleks terhadap partai politik. (David E. Apter, 1987: 195).

Di Negara manapun di dunia ini, sebuah bangsa pasti memiliki orientasi hidup atau apa yang dicita-citakan, keseluruhannya terangkum dalam sebuah ideology. Hal ini, karena ideology sesungguhnya dapat dirumuskan sebagai kompleks pengetahuan dan nilai, yang secara keseluruhan menjadi landasan bagi seseorang (atau masyarakat) untuk memahami jagatnya dan bumi seisinya serta menentuan sikap dasar untuk mengolahnya. Berdasarkan pemahaman yang dihayatinya itu seseorang menangkap apa yang dilihat benar dan tidak benar, serta apa yang dinilai baik dan tidak baik. Dan kemudian seseorang (masyarakat) akan menjalankan kegiatan-kegiatan sebagai perwujudan keseluruhan pengetahuan dan nilai yang dimilikinya, sehingga akan terciptalah suatu dunia kehidupan masyarakat dengan system dan struktur social yang sesuai dengan orientasi ideologisnya (Listiyono Santoso, 292). 
Pada dasarnya partai politik merupakan cerminan dari masyarakat. Masyarakat yang kuat secara ideologis akan mempengaruhi partai politik yang dibentuknya. Dengan demikian seharusnya ideologi bagi partai politik merupakan suatu keniscayaan.

Ketika partai politik tidak mempunyai suatu idelogi maka partai politik tersebut berjalankan tidak memiliki orientasi. Program yang dilaksanakan sangat aplikatif tidak menyentuh pada aspek dasar dari filosofi tujuan pendiriannya. Untuk itu bagi partai politik, ideologi merupakan dasar filosofi dari aktivitas politik mereka. Program-program yang dijalankan oleh partai politik mengacu pada nilai-nilai dari ideologi yang mereka anut. Dan ketika partai politik tersebut konsisten dengan ideologi maka akan lahir program-progam yang menjadikan partai politik tersebut semakin solid.

Rekrutmen politik ideologis merupakan rekrutmen politik yang didasarkan pada ideologi partai politik. Dalam rekrutmen politik tersebut, ideologi partai politik menjadi sumber materi pendidikan, sumber program aktivitas politik dan dasar bagi pengambilan kebijakan politik.

Pancasila sebagai pandangan hidup bangsa terkandung di dalamnya konsepsi dasar mengenai kehidupan yang dicita-citakan, terkandung dasar pikiran terdalam dan gagasan mengenai wujud kehidupan yang dianggap baik. Oleh karena Pancasila sebagai pandangan hidup bangsa merupan kristalisasi daari nilai-nilai yang hidup dalam masyarakat Indonesia, maka pandangan hidup tersebut dijunjung oleh warganya karena pandangan hidup bangsa berakar pada budaya dan pandangan hidup masyarakat.

Orde baru yang sejak awal mengidentifikasikan sebagai satu-satunya pendukung Pancasila, seolah menandai munculnya pertanyaan-pertanyaan mendasar atas kekuatan Pancasila sebagai ideologi dan memberikan spirit nilanya bagi pembentukan masyarakat sipil di Indonesia, agar kesalahan sejarah tidak terulang lagi. Era reformasi ini dihadapkan pada tantangan besar, yaitu tuntutan demokrasi di satu pihak, namun demokrasi tidak disertai penegakan hukum yang jelas, maka yang akan timbul anarkhi (Listiyono Santoso,47).

Ideologi adalah produk kebudayaan suatu masyarakat dan karena itu dalam arti tertentu merupakan manifestasi sosial dari keinginan luhur masyarakat. Artinya perumusan sebuah ideologi (dalam hal ini Pancasila) seharusnya dimaknai dari adanya keinginan untuk mewujudkan suatu struktur dan konstruksi masyarakat yang diidealisasikan, sesuai dengan keadaannya (Listiyono Santoso,48).

Berdasar pada pemahaman ini, maka pada hakikatnya ideologi tidak lain adalah hasil refleksi terhadap kenyataan hidup masyarakat yang terjadi hubungan dialektis, sehingga berlangsung pengaruh timbal balik yang terwujud dalam interaksi yang di satu pihak memacu realitisasi idelogi dan di lain pihak mendorong masyarakat makin mendekati bentuk yang ideal.

Para pengamat politik berpendapat bahwa cara yang paling mutakhir untuk melihat peranan ideologi partai di Indonesia, adalah khususnya mengidentifikasi konflik antar partai politik dan umumnya melihat di antara keseluruhan kekuatan politik. Merujuk pada pendapat Duverger, ada tiga tipe konflik partai politik, yaitu: (1) konflik yang sama sekali tidak mempunyai dasar yang prinsipil; (2) konflik yang timbul karena terdapat perbedaan mengenai bagian-bagin dari suatu prinsip, tetapi tidak mengenai 
prinsip itu sendiri; dan (3) konflik sama sekali bertolak dari suatu prinsip dasar(Elly M.Setiadi \& Usman Kolip, 303)

Merujuk pada pendapat di atas, di era reformasi banyak bermunculan partai-partai politik yang baru dan sekaligus marak terjadi konflik-konflik internal partai politik yang berakhir di pengadilan serta ada yang berakhir dengan perpecahan yang ditandai dengan munculnya dua kepemimpinan.

Di sini peran sebuah ideology itu muncul untuk mempersatukan frame berpikir dan paradigm.

Dari banyak kasus yang menimpa partai politik, di satu sisi partai politik tidak memiliki pandangan yang sama antar partai politik, antar elite partai dan antar pengurus partai mengenai ideology. Dan di sisi lain kepentingan-kepentingan dunia global sangat ingin "menguasai" Indonesia dari berbagai aspek kehidupan.

Peran partai politik yang konsisten dengan ideology yang diusung akan mewarnai lembaga legislative dan akhirnya akan mewarnai pula produk peraturan perundangan-undangan yang dilahirkan oleh lembaga legislative tersebut serta menjamin terselenggaranya pemerintahan yang baik sehingga stabilitas nasional terjaga.

\section{Rekrutmen Politik Berdasarkan Ideologi Partai Politik}

Rekrutmen politik ideologis dimaksudkan bahwa dasar dalam melakukan rekrutmen politik oleh partai politik adalah ideologi yang dianut oleh partai politik tersebut. Untuk itu partai politik harus menterjemahkan ideologi tersebut ke pengertian yang lebih aplikasi. Ideologi partai politik tersebut melahirkan nilai-nilai yang diyakini mampu memberikan kebaikan bagi keberlangsungan partai politik dan masyarakat Indonesia pada umumnya.

Di awal kemunculannya tersebut, partai politik merupakan perwujudan dari aliran, ideologi dan keyakinan masyarakat Indonesia pada masa itu. Sehingga kehadiran partai politik disambut antusias oleh masyarakat, terlebih pada masa revolusi keinginan untuk berpartisipasi dalam politik mendapat tekanan dari penjajah. Dalam sejarah kepartaian, tercatat beberapa ideologi yang diusung oleh partai politik diantaranya adalah ideologi Islam (agama), ideologi nasionalis, ideologi sosialis dan ideologi komunis.

Pada masa orde baru ideologi komunis dinyatakan ideologi terlarang di Indonesia. Di era orde baru, ideologi yang diusung oleh partai politik difusikan oleh pemerintah melalui penyederhanaan partai politik. Sehingga terbentuklah tiga partai politik yang merupakan fusi atau gabungan dari 9 partai politik. Tiga partai politik tersebut yaitu Partai Demokrasi Indonesia (PDI) yang merupakan gabungan dari partai yang berideologi nasionalis, sosialis dan Kristen, Partai Persatuan Pembangunan (PPP) yang merupakan gabungan dari partai yang berideologi Islam (agama), serta Golongan Karya (Golkar) (Manuel Kaiseipo, 1985).

Ketiga partai politik tersebut bertahan sejak tahun 1971 hingga tahun 1998. Tahun 1999 dilakukan amandemen terhadap UUD 1945, termasuk Pasal 28 yang mengatur tentang HAM dilakukan amandemen dengan menambah jumlah ayat pada Pasal 28 tersebut. Sebagai tindak lanjut dari amandemen tersebut maka lahirlah UU No.39 Tahun 1999 tentang Hak Asasi Manusia. 
Lahirnya UU No. 39 Tahun 1999 tersebut membuka kran bagi kemunculan partai-partai politik. Atas dasar kebebasan berserikat dan berkumpul, rakyat Indonesia berbondong-bondong mendirikan partai politik akibatnya Pemilu pertama di era reformasi tahun 1999 diikuti oleh 48 partai politik. Pemilu tahun 2004 diikuti 24 parpol dan Pemilu tahun 2009 diikuti 38 parpol serta Pemilu 2014 diikuti Oleh 12 parpol.

Pada awal reformasi terdapat partai politik yang memperlihatkan ideologi partai politik sebagai jati diri partai. Di antara ideologi partai tersebut mengkrucut menjadi 2 ideologi besar yaitu ideologi Islam dan ideologi nasional. Di antara dua ideologi besar tersebut terdapat partai politik yang menempatkan ideologi di antara keduanya seperti

Perolehan suara partai politik berdasarkan ideologi Islam dan non Islam (Nasionalis) antara lain; (Moch. Nurhasim, 2016:10)

\begin{tabular}{|c|c|c|c|c|}
\hline \multirow{2}{*}{ Pemilu } & \multicolumn{2}{|c|}{ Partai Islam } & \multicolumn{2}{c|}{$\begin{array}{c}\text { Partai Non Islam } \\
\text { (Nasionalis) }\end{array}$} \\
\cline { 2 - 5 } & $\begin{array}{c}\text { Jumlah parpol } \\
\text { peserta Pemilu }\end{array}$ & $\begin{array}{c}\text { Perolehan } \\
\text { suara (\%) }\end{array}$ & $\begin{array}{c}\text { Jumlah parpol } \\
\text { peserta Pemilu }\end{array}$ & $\begin{array}{c}\text { Perolehan } \\
\text { suara (\%) }\end{array}$ \\
\hline 1999 & 19 & 37,59 & 29 & 62,41 \\
\hline 2004 & 7 & 38,54 & 17 & 61,46 \\
\hline 2009 & 9 & 25,94 & 35 & 74,06 \\
\hline 2014 & 5 & 31,39 & 7 & 68,61 \\
\hline
\end{tabular}

Berdasarkan table di atas terdapat perbedaan yang signifikan perolehan suara. Pertanyaan yang muncul apakah yang mendasari para pemilih dalam menentukan pilihannya di Pemilu?. Sebagaimana diketahui penduduk Indonesia mayoritas beragama Islam.

Di sisi lain kemunculan partai-partai baru di era reformasi tersebut seperti memberi sinyal akan kebangkitan suatu ideologi. Untuk itu pada pemerintahan Jokowi sinyal tersebut ditindak lanjuti dengan membentuk Unit Kerja Pembinaan ideologi Pancasila yang dilanjutkan dengan keluarnya Peraturan Presiden Nomor 54 Tahun 2017.

Keinginan presiden Jokowi dengan menerbitkan Perpres tersebut memberi sinyal untuk menegakkan Pancasila sebagai ideologi negara. Jika melihat sejarah ketatanegaraan Indonesia, maka keinginan serupa juga merupakan keinginan Soeharto kala menjabat sebagai Presiden di era orde baru. Di era orde baru Pancasila dijadikan sebagai satu-satunya asas bagi partai politik di Indonesia. Berdasarkan ketentuan tersebut partai politik yang berlatar belakang sejarah Islam dan nasionalis harus mengganti asas menjadi berasaskan Pancasila. Sehingga akhirnya muncul pertanyaan, bagaimana menjadikan Pancasila sebagai asas bagi partai politik yang notabene nya setiap partai politik telah memiliki ideologi partai yang telah tumbuh dan berkembangan di masyarakat.

Dari perkembangan sejarah politik jelas terlihat bahwa ideologi nasionalisme dan Islam tidak akan pernah pudar. Kepudaran ideologi Islam sebagai salah satu "ideologi yang terus diusung oleh sebagian umat Islam dalam politik hanya tergantung pada tipe partai yang didirikan oleh umat Islam dan dukungan politik. Jika performa partai-partai Islam "hilang" dalam konstelasi politik di Indonesia, justru akan mendorong ketidakseimbangan politik di Indonesia (Moch. Nurhasim, 14). 
Terdapat hubungan sebab akibat antara pemilih dengan partai politik, dan partai politik dengan ideologi. Ketika pemilih mayoritas Islam semestinya berkorelasi dengan partai politik Islam. Begitupun partai politik yang mengusung ideologi Islam harus mampu memperlihatkan identitas dan kebijakan yang berkorelasi dengan ideologi Islam. Namun menurut Ramlan Surbakti; identitas partai politik dari segi kebijakan publik tak jelas karena ideologi partai lebih banyak sebagai tontonan daripada tuntunan. Disiplin partai makin lama makin lemah karena fungsi partai sebagai peserta pemilu makin lama makin diambil alih oleh calon. Sehingga akhirnya menyebabkan pemilih yang mengidentifikasikan diri secara psikologik dengan suatu partai semakin kecil (Ramlan Surbakti, 2017: 6).

\section{Rekrutmen Politik Berdasarkan Ideologi Islam}

Suatu ideologi memberikan kekuatan yang nyata terutama dalam membangun identitas dan solidaritas. Ideologi dapat menghilangkan ketakutan dan meningkatkan rasa percaya diri ketika berhadapan dengan kelompok asing dari luar. Ideologi yang bersumber dari agama dimana agama dipahami sebagai tujuan-tujuan pokok yang menjadi tujuan pribadi bagi seseorang dan tujuan budaya bagi masyarakat. Suatu "agama politik" akan menunjuk pada tujuan-tujuan transendetal yang menentukan negara sebagai kesatuan moral. Dalam pengertian ini agama politik merupakan landasan bagi norma-norma suatu masyarakat yang kita sebut sebagai nilainilai kesempurnaan (David E. Apter, 280).

Dalam pemikiran politik Islam, pembahasan perihal hubungan antara agama dan negara telah berlangsung sejak ke khalifahan Rasulullah. Dalam politik gereja hubungan agama dan negara pun telah ada sejak lama. Namun demikian kedua pemikiran tersebut mempunyai cara pandang yang berbeda (tidak sama).

Kalangan pemikir Islam antara lain Al-Farabi, bahwa negara dibagi dua kelompok yaitu negara utama (al-Madinah al-fadilah) dan lawan negara utama (Mudaddah al Madinah al-Fadilah). Dalam negara utama terdapat warga-warga negara dengan fungsi dan kemampuan yang tidak sama satu sama lain. Kebahagiaan masyarakat akan terwujud apabila ada pembagian kerja yang berbeda, sesuai dengan keahlian dan kecakapan anggotanya dengan dijiwai oleh rasa setia kawan dan kerjasama yang baik (Muhammad Iqbal dan Amin Husein Nasution, 2013:.11)

Menurut Yusuf Al- Qardhawy, daulah Islam adalah daulah sipil yang ditegakkan atas dasar pemilihan, baiat dan syuro. Tanggung jawab pemimpin ada di hadapan umat, dan hak setiap rakyat adalah mengingatkan pemimpin itu, menyerunya pada yang ma'ruf dan mencegahnya dari yang munkar. Pemimpin dalam Islam bukan wakil Allah, tetapi ia adalah wakil umat. Umatlah yang berhak memilih, mengawasi, memperhitungkan dan memberhentikannya. (Yusuf Al Qardhawy, 1999: 82-83)

Perkembangan sosial politik masyarakat di era tahun 1990-an mendorong terjadinya perubahan sistem politik Indonesia menuju demokratisasi. Perkembangan sosial politik masyarakat tersebut tidak terlepas dari fase pengembangan dakwah yang telah dirintis sejak tahun 1980-an. Dalam pengembangan dakwah tersebut dilakukan secara bertahap yang terbagi pada empat fase yaitu; mihwar tanzhimi, mihwar sya'bi, mihwar muasasi dan mihwar daulah. Pengembangan pertama terpusat pada 
perbaikan individu, yang dilanjutkan dengan perbaikan keluarga, disusul dengan perbaikan masyarakat dan terakhir perbaikan pada level negara (Firman Noor, 2015: 111).

Di era reformasi, Islam sebagai ideologi partai politik diusung secara lantang oleh Partai Keadilan Sejahtera (PKS). Sebelum menjadi partai politik terjadi proses islamisasi masyarakat secara bertahap oleh gerakan dakwah. Di akhir tahun 1990-an, sebagai kelanjutan dari proses pentahapan dakwah, gerakan dakwah selanjutnya masuk dunia politik. Masuknya dakwah dalam dunia politik merupakan respon terhadap perkembangan terkini dalam perpolitikan Indonesia. Jatuhnya rezim Soeharto, membuka kran demokrasi yang bebas dan terbuka. Era kebebasan dan keterbukaan tersebut dimanfaatkan bagi gerakan dakwah untuk menyebarkan dakwah secara terbuka kepada seluruh umat Islam. Dan akhirnya gerakan dakwah berhasil mendirikan partai politik pada 9 Agustus 1998 dengan nama Partai Keadilan (PK). Setelah lima tahun keberadaannya di kancah politik nasional disebabkan oleh regulasi ambang batas mengakibatkan PK di diskualifikasi sehingga tidak dapat mengikuti pemilu berikutnya. Selanjutnya pada tahun 2003 PK secara resmi menyatakan diri sebagai bagian dari Partai Keadilan Sejahtera yang dideklarasikan pada 20 April 2002.

Doktrin Syumuliatul Islam melahirkan doktrin tsawabit wa mutaghayyirat. Doktrin ini menjelaskan dua aspek ajaran Islam yaitu tsawabit (aspek fundamental) dan Mutaghayyirat (aspek dinamis). Tsawabit berkaitan dengan masalah-masalah yang secara jelas dinyatakan dan diatur di dalam Al Qur'an dan Hadist. Aspek ini berkaitan dengan hukum yang telah ditetapkan oleh Allah sehingga bersifat absolut dan abadi. Adapun mutaghayyirat terkait dengan berbagai persoalan yang tidak secara komprehensif dijelaskan di dalam Al Qur'an dan Hadist. Secara teoritis, hal ini dikenal sebagai furu (masalah cabang). Atas dasar doktrin ini, partai politik dapat mengadobsi pandangan politik apapun sepanjang tidak bertentangan dengan fondasi ajaran Islam. Pandangan ini memberikan fleksibilitas dalam menerima konsep politik modern termasuk menggunakan demokrasi sebagai mekanisme untuk mencapai tujuan politik (Firman Noor, 2015: 120).

Terkait dengan rekrutmen politik, PKS mempunyai komitmen untuk melakukan kaderisasi secara sistematis dan bertahap. Proses ini ditujukan untuk membentuk individu yang gigih dan siap untuk melaksanakan dakwah partai. Untuk kepentingan ini, PKS melembagakan proses kaderisasi ke dalam konstitusi partai. Melalui Departemen Kaderisasi, PKS menerbitkan materi kaderisasi, dimana materi kaderisasi Jamaah Tarbiyah menjadi rujukan utamanya. (Firman Noor, 2015:124)

Dalam Pasal 28 ayat (2) AD/ART PKS mengatur bahwa rekrutmen jabatan politik untuk calon Anggota DPR Dan DPRD dilakukan melalui suatu proses penjaringan dan penyaringan dengan memperhatikan; a) jenjang keanggotaan; b) kapabilitas dan profesionalitas; dan c) keterwakilan perempuan.

Selain berdasarkan kaderisasi sistematis, dalam melakukan rekrutmen politik, PKS juga membuka peluang pihak luar terutama pakar atau tokoh masyarakat untuk menjadi caleg PKS. Untuk jenis rekrutmen ini, partai membentuk sebuah tim yang memonitor dan mengecek kualitas kepribadian dan komitmen keislaman tokoh yang berpotensi tersebut. 
Setelah partai memutuskan nama-nama kandidat yang layak untuk menjadi caleg PKS, partai kemudian membangun kedekatan personal terhadap kandidat-kandidat tersebut dan meyakinkan mereka agar bersedia menjadai caleg PKS dan membuat kesepakatan antara partai dan para kandidat tersebut. Bagi kandidat yang pada akhirnya berhasil terpilih dalam Pemilu, partai akan meminta mereka untuk bergabung pada gerakan dakwah tarbiyah atau sekurang-kurangnya memberikan kontribusi terhadap agenda dan kegiatan partai termasuk mengikuti Taklim Rutin Kader (TRK).

Dalam Panduan Dewan Pengurus Pusat (DPP) Nomor 4 Tahun 2016 diatur tentang mekanisme pencalonan anggota legislative di PKS dilaksanakan dengan dua tahapan yaitu seleksi Bakal Calon Anggota Dewan Perwakilan Rakyat yang disingkat BCAD dan seleksi Calon Anggota Dewan Perwakilan Rakyat yang disingkat CAD. Dalam seleksi BCAD dan CAD tersebut dilakukan berdasarkan prinsip antara lain; a) memperhatikan nilainilai dakwah yang dianut oleh partai; b) menjaga keseimbangan antara kepentingan structural partai dan perjuangan konstitusional di DPR dan DPRD; c) mengutamakan ukhuwah islamiyah dalam seluruh tahapan; d) mempertimbangkan aspek manfaat dan mudharatnya; e) mengutamakan nilai-nilai keluhuran akhlak, kecakapan, dan kelayakan, di atas popularitas dan kemampuan operasional; f) mengutamakan asas demokratis dan aspiratif; g) mempertimbangkan kekokohan dan daya dukung keluarga; dan h) mengedepankan nilai-nilai proporsionalitas.

Penempatan bakal calon ditentukan oleh jenjang tertentu misalnya untuk ada partai politik yang mensyaratkan calon yang akan duduk sebagai calon anggota DPR mempunyai jenjang minimal sebagai anggota dewasa sedangkan sebagai calon anggota DPRD minimal memiliki jenjang anggota inti.

Dalam Peraturan Lembaga Pelaksana Penokohan Kader Tentang Petunjuk Pelaksanaan dan Petunjuk Pelaksanaan dan Petunjuk Teknis Dalam Penyaringan Bakal Calon Anggota Dewan Perwakilan Rakyaat dan Dewan Perwakilan Rakyat Daerah untuk Pemilihan Umum Tahun 2019, Pasal 4-Pasal 6, ditentukan bahwa; Partai Keadilan Sejahtera (PKS) salah satu partai politik peserta Pemilu mempunyai mekanisme penentuan Bakal Calon Anggota Dewan (BCAD) melalui mekanisme penyaringan yang terdiri dari dua tahap yaitu tahap satu mencakup seleksi administrasi, kualitas dan integritas, yaitu tahap inventarisasi daftar nama bakal calon yang disahkan oleh Lembaga Pelaksana Penokohan Kader (LPPK). Daftar bakal calon tersebut selanjutnya diberikan rekomendasi berdasarkan pertimbangan keaktifan dalam kegiatan kaderisasi partai, kedisiplinan, wawasan dan jaringan politik, mempunyai kemampuan komunikasi yang baik, memiliki citra bersih baik moral maupun hukum, mempunyai kemampuan memperjuangkan aspirasi rakyat di daerah pemilihannya, dan mempunyai keluarga yang siap mendukung perjuangan.

Selanjutnya tahap kedua mencakup penilaian kinerja Bakal Calon Anggota Dewan (BCAD) yang bersangkutan terhadap; a) hasil elektabilitas dalam pemilihan umum; 2) dukungan konstituen; 3) dan terbinanya komunikasi yang efektif dengan struktur partai. Setelah selesai seleksi tahap kedua, maka LPPK melaporkan hasil penyaringan tersebut sebanyak $100 \%$ dari jumlah kuota anggota dewan beserta daerah pemilihannya kepada Dewan Pimpinan Tingkat Pusat (DPTP), selanjutnya ditetapkan oleh DPTP. 
(Lembaga Pelaksana Penokohan Kader Partai Keadilan Sejahtera No. 02 Tahun 2016)

PKS sebagai partai politik yang berasaskan Islam menjadikan Islam sebagai landasan dan rujukan dalam kaderisasi. Kaderisasi PKS memiliki dua fungsi utama, yaitu melakukan pengembangan kualitas kader dan sebagai basis rekrutmen untuk mengisi posisi internal partai dan anggota parlemen. Pelaksanaan fungsi ini dilakukan dengan terbuka di seluruh infrastruktur dan lembaga-lembaga partai. Partai menyadari bahwa kekuatan utama partai tergantung pada pertumbuhan kader, baik dalam aspek kualitas maupun kuantitas. (Firman Noor:332).

Pola pengkaderan secara sistematis dilaksanakan melalui melalui Departemen Kaderisasi menyediakan seperangkat dan pedoman praktis pelaksanaan kaderisasi dan mengkomunikasikannya ke seluruh departemen kaderisasi seluruh Indonesia. Setiap kader harus mengikuti progam dan kegiatan yang telah ditetapkan oleh Departemen Kaderisasi tersebut. Salah satunya adalah Taklim Rutin Partai (TRK). TRK ini merupakan training wajib mingguan yang dihadiri maksimal 12 kader. Setiap kelompok TRK dibimbing oleh seorang mentor yang disebut dengan murobbi. Dalam pertemuan TRK yang dilakukan seminggu sekali tersebut diberikan materi berkaitan dengan pemantapan ideology, visi misi dakwah, konsep loyalitas dan kepercayaaan kepada partai dan para pemimpinnya. Selain itu juga diberikan materi yang berkaitan dengan pengembangan individu kader (Firman Noor:336).

Bentuk evaluasi menjadikan TRK berperan layaknya sekolah. Di dalamnya ada kewajiban untuk membuat laporan periodik tentang kemajuan siswa atau kader. Dengan adanya evaluasi sistematis ini, partai pada akhirnya mampu menyupervisi seluruh perkembangan kader, termasuk kapasitas kader untuk menyerap berbagai materi bahasan kaderisasi melalui murobbi sebagai perangkat partai (Firman Noor: 342 ).

\section{Rekrutmen Politik Berdasarkan Selain Islam}

Ideologi partai yang tumbuh selain Islam adalah nasionalis dan koalisi partai politik. Istilah nasionalisme biasa didengar ketika menghadapi penjajahan atau ketika perjuangan kemerdekaan. Seruan nasionalisme begitu membahana, khususnya di kalangan bangsa-bangsa timur yang , menganggap bahwa bangsa eropa barat telah melecehkan keberadaannya, merendahkan martabat dan merampas kemerdekaan mereka. Bukan hanya itu, eropa barat pun juga mengeksploitasi harta kekayaan mereka.

Setiap bangsa yang merasakan penjajahan tentu memiliki perasaan nasionalisme yang tinggi. Sebagaimana menurut Burke, bangsa adalah suatu ikatan dari semua generasi yang tidak boleh diubah atau dipatahkan sedikitpun. (Lyman Tower Sargent \& A.R.Hendry Sitanggang,1987:19).

Perasaan nasionalisme yang menggetarkan telah ditunjukkan dan dipertahankan dalam perjuangan kemerdekaan Republik Indonesia tahun 1945. Ajaran nasionalisme ini pertama kali dikumandangkan oleh bung Karno ketika hendak mengajak para pemuda untuk merebut kemerdekaan dari penjajah Jepang serta memerdekakan Indonesia. Ajaran nasionalisme ini, dimaksudkan untuk mengingatkan rakyat Indonesia bahwa menjaga persatuan dan kesatuan bangsa adalah sangat penting sebagaimana telah dicantumkan dalam Pembukaan UUD 1945 (Suwelo Hadiwijoyo, 2013:17) 
Rasa nasionalisme inipun yang mengilhami masyarakat Indonesia untuk mendirikan partai politik. Spirit nasionalisme ini menjadi salah satu tujuan perjuangan politik untuk mempertahankan kemerdekaan. Sejarah memperlihatkan spirit nasionalisme telah mendorong partai politik berjuang menghadapi Agresi Belanda I dan Agresi Belanda II melalui meja perundingan serta peran partai politik untuk mengembalikan Negara Kesatuan Republik Indonesia setelah sempat berubah menjadi Negara Republik Indonesia Serikat (NRIS) pada tahun 1949.

Spirit nasionalisme menumbuhkan semangat solidaritas dan identitas. Semangat solidaritas yang ditumbuhkan melahirkan rasa persatuan dan kesatuan, rasa kecintaan yang mendalam terhadap tanah air dan bangsa. Serta dicirikan dengan symbol-symbol yang mencerminkan suatu identitas bersama. Dengan identitas tersebut, partai politik yang bersangkutan mudah dikenali dan diingat oleh masyarakat.

Di era reformasi saat ini, partai politik dituntut untuk memiliki rasa nasionalisme yang tertuang dalam AD/ART partai. Semangat nasionalisme yang berkembang saat ini adalah semangat menjaga keutuhan Negara Kesatuan Republik Indonesia (NKRI).

Salah satu partai yang mengusung nilai nasionalisme adalah Partai Demokrasi Indonesia Perjuangan. Keberadaan Partai Demokrasi Indonesia Perjuangan yang disingkat PDIP tidak terlepas dari perjalanan panjang kepartaian di Indonesia. Sejarah kepartaian yang diawali dari dilakukannya penyederhanaan sistem kepartaian dengan mengurangi jumlah partai politik melalui Penpres No. 7/1959. Dalam Penpres tersebut Maklumat Pemerintah 3 November 1945 yang menganjurkan pembentukan partai politik dicabut dan menetakan syarat-syarat yang harus dipenuhi oleh partai untuk diakui oleh pemerintah. Partai-partai yang dinyatakan memenuhi syarat-syarat yang ditetapkan tersebut adalah PKI, PNI, NU, Partai Katolik, Partindo, Parkindo, Partai Murba, PSII Arudji, IPKI dan Partai Islam Perti. Sedangkan beberapa partai lain dinyatakan tidak memenuhi syarat. Partai Masyumi dan PSI dibubarkan pada tahun 1960 sehingga yang tersisa tinggal sepuluh partai politik saja (Miriam Budiardjo: 441).

Lahirnya PDIP tidak terlepas dari pengaturan penyederhanaan partai politik yang terjadi sejak 1971 dan 1973. Pada 1973 diterbitkan UU No. 3 Tahun 1973, berdasarkan undang-undang tersebut pemerintah melakukan penyerhanaan partai politik melalui kebijakan fusi partai. Ada lima partaipartaiyaitu PNI, Partai Kristen Indonesia, Partai Katolik, Partai Murba dan IPKI bergabung menjadi Partai Demokrasi Indonesia (PDI). Sehingga pada tahun 1977 hanya ada tiga organisasi politik yaitu PPP, PDI dan Golkar dan ini bertahan sampai dengan Pemilu pada tahun 1997 (Labolo: 98).

Setelah melalui proses yang panjang akhirnya pada tanggal 10 Januari 1973 tepat jam 24.00 dalam pertemuan Majelis Permusyawaratan Kelompok Pusat (MPKP) yang mengadakan pembicaraan sejak jam $20.30 \mathrm{di}$ Kantor Sekretariat PNI di Jalan Salemba Raya 73 Jakarta, Kelompok Demokrasi dan Pembangunan melaksanakan fusi 5 Partai Politik menjadi satu wadah Partai yang bernama Partai Demokrasi Indonesia. Deklarasi ditandatangani oleh wakil kelima partai yaitu MH. Isnaeni dan Abdul Madjid mewakili Partai Nasional Indonesia, A. Wenas dan Sabam Sirait Mewakili Partai Kristen Indonesia, Beng Mang Rey Say dan FX. 
Wignyosumarsono mewakili Partai Katolik, S. Murbantoko R. J. Pakan mewakili Partai Murba dan Achmad Sukarmadidjaja dan Drs. Mh. Sadri mewakili Partai Ikatan Pendukung Kemerdekaan Indonesia (IPKI). Dengan dideklarasikannya fusi kelima partai tersebut, Partai Demokrasi Indonesia ( wWw.pdi-perjuangan.or.id/info/sejarah-partai-pdi-perjuangan

Berdasarkan profile partai dikatakan bahwa seiring perjalanan perpolitikan nasional dan perjalanan PDI, pada tahun 1993 PDI mengalami perpecahan. Megawati yang terpilih secara aklamasi sebagai ketua umum partai, kemudian diganggu kepemimpinannya melalui kongres PDI di Medan tahun 1996 yang memilih Soerjadi sebagai ketua umum yang baru. Hasil kongres tersebut ditindaklanjuti dengan upaya pengambilalihan PDI dari kepemimpinan Megawati hingga meletus peristiwa kerusuhan tanggal 27 Juli 1996 (Kuda Tuli). Akhirnya pasca kerusuhan tersebut, Megawati kemudian mendirikan Partai Demokrasi Indonesia Perjuangan tepatnya berdiri pada tanggal 10 Januari 1999 dan berkantor pusat di Lenteng Agung Jagakarsa, Jakarta Selatan.

\section{Rekrutmen Melalui Koalisi Partai Politik}

Setelah reformasi dualisme di atas berangsur untuk dihilangkan. Dengan diarahkannya perubahan UUD 1945 ke sistem presidensil. Perubahan tersebut dapat diketahui dengan dilakukannya pemilihan Presiden dalam mekanisme pemilihan secara langsung. Presiden tidak sebagai mandataris MPR lagi. Sebaliknya Presiden adalah pemegang kedaulatan rakyat untuk itu kedudukannya adalah kuat. Presiden tidak dapat diberhentikan sewaktuwaktu oleh DPR/MPR kecuali telah melalui proses hukum di Mahkamah Konstitusi.

Upaya pemurnian sistem pemerintahan presidensial dalam amandemen UUD 1945, tampaknya disadari sebagai suatu kebutuhan untuk merekonstruksi sistem ketatanegaraan, dalam membangun stabilitas pemerintahan dan demokrasi pasca reformasi. Itu menunjukkan bahwa sebelum amandemen UUD 1945 baik secara konseptual maupun praktikal, menunjukkan dua kelemahan dalam mencapai harmoni antara stabilitas pemerintahan pada satu sisi dan demokrasi pada sisi lainnya. Ketika pintu demokrasi dibuka dengan multipartai, kecendrungan pemerintahan mengalami instabilitas, dan pada saat yang sama terkadang dijadikan alasan oleh pemerintah untuk membatasi partai dengan cara-cara otoriter (Firdaus: 376).

Peralihan pemerintahan otoriter ke demokrasi umumnya diapresiasi dengan peningkatan partisipasi politik rakyat dalam pemerintahan. Berbagai asosiasi dan perkumpulan terbentuk untuk berpartisipasi mengambil bagian guna mempengaruhi proses pengambilan kebijakan. Bahwa partai politik adalah bentuk asosiasi paling potensial dan paling efektif untuk berpartisipasi secara langsung, dalam mempengaruhi berbagai kebijakan pemerintahan. Terbentuknya banyak partai politik, baik disebabkan oleh fusi maupun berdiri partai politik baru dalam era demokrasi pertanda bahwa gagalnya pelembagaan partai dalam mengartikulasi aspirasi nilai dan kepentingan (Firdaus: 382 )

Kehadiran partai politik merupakan konsekuensi dari sistem demokrasi. Demokrasi sebagai suatu sistem pemerintahan dari rakyat haruslah sesuai dengan filsafat hidup rakyat itu sendiri. Sebagaimana 
tertuang dalam UUD 1945 maka demokrasi yang diterapkan selain mengakui adanya kebebasan dan persamaan hak juga sekaligu mengakui perbedaan serta kebhinekaragaman mengingat Indonesia adalah "Bhinneka Tunggal Ika", berdasar pada moral persatuan, ketuhanan, dan kemanusiaan yang adil dan beradab (Kaelan, 2013: 585).

Selama perjalanan reformasi ini, multipartai diupayakan dapat mendukung jalannya pemerintahan yang stabil. Untuk itu jumlah partai politik yang banyak diarahkan untuk dilakukan koalisi antar partai. Untuk itu dapat dikatakan partai politik yang tumbuh di era reformasi ini berorientasi pada kompromi-kompromi politik dan di satu sisi fungsi partai politik tidak berjalan sebagaimana yang diharapkan.

Menurut Jimly Asshiddiqie untuk memurnikan sistem presidensial maka dalam hal ini seharusnya pemilihan presiden dan pemilihan anggota legislatif dapat dilakukan serentak, sehingga partai apa saja yang sudah dinyatakan memenuhi syarat sebagai peserta pemilihan umum, dapat mengusulkan calon presiden dan calon wakil presiden. Dua atau lebih partai politik peserta pemilu dapat saja mengadakan koalisi atau bergabung dalam mengajukan calon presiden dan calon wakil presiden. Jika mekanisme demikian dijalankan, maka akan dapat dijamin adanya pola hubungan eksekutif-legislatif yang terpisah atas dasar eksistensi yang pasti antara lembaga kepresidenan dan lembaga parlemen masing-masing menurut Undang-undang Dasar. Dengan demikian, koalisi juga dapat diadakan secara pasti dan mengikat pada tiga tingkatan sekaligus, yaitu:

1. Koalisi atau gabungan partai dalam pencalonan presiden dan wakil presiden (pre electoral coalition);

2. Koalisi dalam pembentukan kabinet (government formation), yang dilakukan secara terintegrasi dengan;

3. Koalisi dalam struktur barisan mayoritas versus minoritas di DPR RI (establishment of parliamentary structure).

Dalam rangka penguatan terhadap pemerintah perlu dipahami bahwa negara Indonesia sejak awal berdirinya telah tumbuh di atas ke-bhinekaan yang ada. Maka dari itu berdirinya banyak partai politik di satu sisi merupakan suatu keniscayaan.

Pada Pilpres tahun 2014 dibentuk koalisi permanen di parlemen antara pendukung Prabowo-Hatta dan Jokowi-Kalla. Pendukung PrabowoHatta mengatasnamakan dirinya dengan sebutan koalisi "Merah Putih" yang didukung Gerindra, Golkar, PKS, PAN dan PPP. Sementara pendukung Jokowi-Hatta mengatasnamakan dirinya sebagai koalisi "Indonesia Hebat" yang dipelopori oleh PDIP, PKB, Nasdem, dan Hanura. Sementara Demokrat memilih "netral", meskipun secara tersembunyi lebih condong ke koalisi Merah Putih.

Persyaratkan yang ditentukan dalam peraturan perundang-undangan tersebut merupakan persyaratan umum dan formal administrasi. Di samping syarat formal tersebut terdapat juga syarat yang bersifat khusus yang ditentukan oleh masing-masing partai politik antara lain: Ketentuan yang terdapat dalam AD/ART PKS juga mengatur tentang rekrutmen jabatan politik untuk calon presiden dan wakil presiden, gubernur dan wakil gubernur, bupati dan wakil bupati, dan walikota dan wakil walikota dilakukan dengan suatu proses penjaringan dan penyaringan dengan 
memperhatikan mekanisme yang demokratis dan terbuka serta kapabilitas dan professionalitas.

Koalisi partai politik di daerah merupakan cerminan dari dinamika demokrasi lokal. Pelaksanaan demokrasi lokal tidak terlepas dari pengaruh perkembangan politik secara nasional. Pengaruh tersebut dapat terlihat pada komposisi koalisi di daerah masih perlu "restu" dari pengurus partai di tingkat pusat. "Restu" yang dimaksud dapat berbentuk koalisi yang dilakukan di tingkat pusat dilaksanakan juga di daerah, misalnya di tingkat pusat partai A berkoalisi dengan partai B maka di tingkat pusat pun demikian. Akan tetapi ada juga partai politik A yang berkoalisi dengan partai $\mathrm{C}$ di tingkat pusat sedangkan di di tingkat daerah partai A dapat berkoalisi dengan partai $\mathrm{D}$ berdasarkan perkembangan demokrasi dalam masyarakat dan juga berdasarkan kemanfaatkan bagi masyarakat. Menimbang demi kepentingan masyarakat partai politik dapat "menerobos" ideologi yang diusung oleh partai yang bersangkutan.

Terkait dengan itu, menurut teori Powercube, politik dibagi menjadi tiga level, yakni politik global, politik nasional dan politik lokal. Politik global merupakan politik di tingkat dunia yang menyangkut persoalan hubungan antarnegara, antarkawasan, atau antarbenua. Isu-isu yang diangkat seputar masalah demokrasi, hak asasi manusia, iklim, energy, kemiskinan, pemanasan global dan beberapa isu penting lainnya (Abdul Chalik: 24).

Politik nasional merupakan persoalan politik di tingkat negara. Di Indonesia isu yang diangkat beragam seperti isu yang berkaitan dengan kesatuan dan persatuan, penguatan paham Pancasila, otonomi daerah, pemilu, kekuasaan, politik di legislative atau istana dan seterusnya. Sedangkan politik lokal, menujuk pada wilayah geogratis, wilayah provinsi, kabupaten dan kota. Isu yang diangkat seperti demokrasi lokal, birokrasi, partisipasi warga, akuntabilitas pemerintah daerah dan sebagainya (Abdul Chalik: 25).

Perubahan mekanisme pemilihan kepala daerah dari tidak langsung menjadi langsung merupakan salah satu dari pengaruh perubahan ketatanegaraan secara nasional. Yang menarik dari setiap pemilihan kepala daerah adalah kemenangan incumbent (petahana) di beberapa kabupaten/kota. Sisi lain adalah keterlibatan elite politik lokal yang dominan, di mana mereka memegang kendali atas kemenangan beberapa pemimpin daerah. Banyak faktor yang menyebabkan kemenangan tersebut di antaranya; jaringan kekuasaan, pendanaan, mobilisasi massa dan dukungan dari koalisi partai politik (Abdul Chalik: 139).

Rekrutmen presiden melalui penjaringan tokoh politik atau dinasti politik dan tokoh masyarakat serta tokoh pemerintahan merupakan salah satu cara yang ditempuh oleh partai politik. Penjaringan melalui tokoh politik atau dinasti politik, misalnya dari dinasti Soekarno melahirkan tokoh politik Megawati, dinasti Soeharto melahirkan tokoh Siti Hardiyanti. Dinasti Soeharto dibangun dengan menempatkan anak dan menantunya pada berbagai posisi menentukan dalam cabinet. Terdapat dua alasan yang mendorong Soeharto untuk menanam pohon politik dinasti tersebut. Pertama, untuk menumbuhkan karir Mbak Tutut yang relative lebih mampu dalam bidang politik disbanding anak-anak Soeharto yang lain. Kedua, Soeharto berharap kepentingan politik dan ekonomi dinastinya tetap terpelihara. Selanjutnya Penjaringan dari tokoh masyarakat, misalnya 
kemunculan Gusdur dari golongan Nahdatul Ulama (NU) dan Amin Rais dari golongan Muhammadiyah. Serta ada juga penjaringan dari tokoh pemerintahan misalnya mantan menteri, mantan kepala daerah dan tokoh pejabat public lainnya (Bambang Cipto,1999:57)

Politik dinasti merupakan dinasti yang memainkan peran utama dalam permainan politik tingkat atas sementara rakyat pemilih hanya bermain di pinggiran. Dalam pola ini nyaris tidak ada tempat bagi politisi yang tidak memiliki jalinan dengan darah biru dari pada pendiri dinasti politik.

\section{Kesimpulan}

Rekrutmen politik ideologis merupakan rekrutmen politik yang didasarkan pada ideologi partai politik. Dalam rekrutmen politik tersebut, ideologi partai politik menjadi sumber materi pendidikan, sumber program aktivitas politik dan dasar bagi pengambilan kebijakan politik. Rekrutmen politik ideologis dilaksanakan oleh partai politik yang mendasarkan aktivitas partainya pada ideologi tertentu. Dalam sejarah kepartaian di Indonesia, ideologi yang digunakan oleh partai politik antara lain ideologi agama (Islam) dan ideologi selain Islam seperti nasionalis dan sebagainya. Rekrutmen politik merupakan salah satu bentuk aktivitas politik. Rekrutmen politik ideologi melahirkan pola rekrutmen yang tersistematis dan terstruktur. Pola rekrutmen tersebut dapat dilihat dari mekanisme rekrutmen yang dilakukan secara terus menerus, terkoordinir, terevaluasi dan berjenjang. Penempatan setiap kader pada posisi-posisi strategis partai ditentukan berdasarkan jenjang pengkaderan yang dilakukan dari awal seseorang masuk sebagai anggota partai politik. Sebaliknya pola rekrutmen yang tidak berdasarkan pada ideologi partai politik dilakukan berdasarkan kepentingan tertentu atau berdasarkan asas kemanfaatan tertentu. Pola rekrutmen seperti ini biasanya dilakukan melalui pendekatan-pendekatan kekeluargaan dan ketokohan.

\section{Daftar Pustaka}

Alfian, 1990, Masalah Kepemimpinan, dalam buku Masalah dan prospek Pembangunan Politik Indonesia, PT Gramedia, Jakarta.

Arbi Sanit, 1987, Sistem Politik Indonesia; Kestabilan Peta Kekuatan Politik dan Pembangunan, CV Rajawali, Jakarta.

Abdul Chalik, 2017, Pertarungan Elit Dalam Politik Lokal,Pustaka Pelajar, Yogyakarta.

Bambang Cipto, 1999, Indonesia Memasuki Era Politik Dinasti, dalam buku berjudul Dari Bilik Suara Ke Masa Depan Indonesia:Potret Konflik Politik Pasca Pemilu dan Nasib Reformasi, PT RajaGrafindoPersada, Jakarta

David E. Apter,1987, Politik Modernisasi, Gramedia, Jakarta

Elly M. Setiadi \& Usman Kolip, 2013, Pengantar Sosiologi Politik, Prenadamedia, Jakarta

Erfandi, 2014, Parliamentary Threshold dan HAM Dalam Hukum Tatanegara Indonesia, Setara Press, Malang

Firman Noor, 2015, Perpecahan \&Soliditas Partai Islam di Indonesia, LIPI, Jakarta. 
Firmansyah, 2011, Mengelola Partai Politik, Komunikasi dan Positionning Ideologi Politik di Era Demokrasi, Yayasan Obor Indonesia, Jakarta.

Firdaus, 2015, Desain Stabilitas Pemerintahan Demokrasi \& Sistem Kepartaian, Yrama Widya, Bandung

Jimly Asshiddiqie, 2015, Penguatan Sistem Pemerintahan dan Peradilan, Sinar Grafika, Jakarta

Kaelan, 2013, Negara Kebangsaan Pancasila, Paradigma, Yogyakarta

Listiyono Santoso, 2003, Dekonstruksi Ideologi Negara, Ning-Rat, Yogyakarta

Lili Romli, 2016, Dinamika Partai Politik Islam di Indonesia: Perspektif Historis, dalam buku berjudul, Masa Depan Partai Islam di Indonesia, Pustaka Pelajar, Yogyakarta.

Lyman Tower Sargent \& A.R. Hendry Sitanggang, 1987, Ideologi-Ideologi Kontemporer Sebuah Analisis Komparatif, Erlangga, Jakarta

Lembaga Pelaksana Penokohan Kader Partai Keadilan Sejahtera No. 02 Tahun 2016, Peraturan Lembaga Pelaksana Penokohan Kader Tentang Petunjuk Pelaksanaan dan Petunjuk Pelaksanaan dan Petunjuk Teknis Dalam Penyaringan Bakal Calon Anggota Dewan Perwakilan Rakyaat dan Dewan Perwakilan Rakyat Daerah untuk Pemilihan Umum Tahun 2019.

Muhammad Iqbal \& Amin Husein Nasution, 2013, Pemikiran Politik Islam Dari Masa Klasik Hingga Indonesia Kontemporer, Kencana Prenada Media Group,Jakarta.

Manuel Kaiseipo, 1985, Dilema Partai Demokrasi Indonesia: Perjuangan Mencari Identitas, Dalam Majalah Prisma Analisa Kekuatan Politik di Indonesia, LP3ES, Jakarta

Riswanda Imawan, 1998, Membedah Politik Orde Baru, Pustaka Pelajar, Yogyakarta.

Suwelo Hadiwijoyo, 2013, Ajaran-Ajaran Spektakuler Bung Karno dan Pak Harto, IRCiSoD, Yogjakarta

Yusuf Al Qardhawy, 1999, Fiqih Daulah Dalam Perspektif Al Qur'an dan Sunnah, Pustaka Al Kautsar, Jakarta.

https://Www.pdi-perjuangan.or.id/info/sejarah-partai-pdi-perjuangan/21 Feb 2009 